Int. J. Morphol.,

35(1):233-235, 2017

\title{
Dorello's Canal or Abducens Nerve Canal: Constancy or Inconstancy?
}

\author{
El Canal de Dorello o Canal para el Nervio Abducente: ¿Constancia o Inconstancia?
}

\author{
Jorge Eduardo Duque Parra ${ }^{1,2}$; John Barco Ríos ${ }^{2}$ \& Julián Mendoza Zuluaga²
}

DUQUE, P. J. E.; BARCO, R. J. \& MENDOZA , Z. J. Dorello's canal or abducens nerve canal: Constancy or inconstancy? Int. J. Morphol., 35(1):233-235, 2017.

SUMMARY: Dorello's canal is an eponym term referring to a small fibro osseous landmark, by way of arc, located at the apex of the petrous temporal region and for which the nerve abducens passes before reaching the cavernous sinus. This landmark is not referenced in Terminologia Anatomica, even as a variable structure. We selected 74 adult dry skulls and six heads fixed in formalin $10 \%$ without classifying them by ethnicity or gender. As inclusion criteria, we selected those where the middle cranial fossa and the apex of the petrous temporal region were in good condition. Fifty seven (57) skulls $(83,82 \%)$ showed the presence of canal bilaterally; $4(5.89 \%)$ showed it unilaterally to the right; $4(5,89 \%)$ were unilaterally at the left and $3(4,41 \%)$ had no canal. The results of this study indicate that this bone landmark is present in most of the skulls, even bilaterally. Since it is not referenced in the Terminologia Anatomica, we propose the term canal abducens nerve to avoid using the eponymous term Dorello's canal.

KEY WORDS: Petrous temporal region; Apex; Canal; Abducens nerve; Terminology.

\section{INTRODUCTION}

The first descriptive study of the area where the abducens nerve passes at the apex of the petrous temporal region was performed by Russian anatomist Wenzel Gruber in 1859 (Marom, 2011; Ezer et al., 2012). Gruber described the ligament extending from the apex of the petrous temporal and sphenoid posterior clinoid process and gave the name petrosphenoidal ligament (Marom; Ambekar et al., 2012). Later, in 1872, Italian anatomist Primo Dorello conducted a more detailed study of this area, which describes the connection between the apex and posterior clinoid process forms a hollow bone, ligament and the petrosphenoidal close this concavity at its upper edge forming one fibro osseous canal, often referred to by the eponym of "Dorello's canal" (Forbis, 1998). This canal is between 6 to $12 \mathrm{~mm}$ long and 1-3 mm wide, which contains the lower petrosal sinus and sixth cranial nerve (Marom; Ambekar et al).

The arc-shaped canal, through which the abducens nerve courses before reaching the cavernous sinus within a venous junction in the petroclival area (Umansky et al., 1991; Destrieux et al., 1997). The petroclival venous confluence, which has a square shape in cross section lies between two dural leaves of the petroclival area: an inner (or brain) and outer (or osteoperiosteal) (Destrieux et al). The petrosphenoidal ligament divides the petroclival venous confluence in two compartments, top and bottom, the latter being generally compartment where the abducens nerve passes, binding to the surrounding dura mater (Destrieux et al).

The apex of the petrous region is a complex area which is surrounded by the cavernous sinus, abducens canal nerve and trigeminal cavum. The petrosphenoidal and the petrolingual ligament that form the bottom of the falciform ligament (Ambekar et al), are important structures in this region, and knowledge of its anatomical relations with neurovascular structures is a prerequisite before surgery in this area (Liu et al., 2009). Also know histologically, the petroclival nerve segment is covered by a sheath composed of a layer of arachnoid cells (Ono et al., 2004). The Dorello's canal is the only area where the VI cranial nerve can be compressed by an inflammatory process (Ambekar et al; Felisati \& Sperati, 2009), or the canal be obstructed because of sarcoidosis, which can lead to palsy of the abducens nerve (Shioya et al., 2014).

\footnotetext{
${ }^{1}$ Departamento de Ciencias Básicas Biológicas, Universidad Autónoma de Manizales, Manizales, Colombia.

${ }^{2}$ Departamento de Ciencias Básicas, Programa de Medicina, Universidad de Caldas, Manizales, Colombia.
} 
The detailed knowledge of the area where Dorello's canal has elucidated the mechanism of cranial nerve VI palsy in several pathological conditions, such as intracranial pressure, hypoplasia of the canal (Chua et al., 2011), aneurysms and Gradenigo syndrome caused by infection and inflammation of the apex (Ambekar et al). Currently, interest in this anatomical structure has become important due to the advances that have been made in surgery of the skull base (Tsitsopoulos et al, 1996; Ezer et al., 2012) to treat tumors in the petroclival region (Kshettry et al., 2013).

However, despite all detailed anatomical descriptions that have been made, Dorello's canal and its clinical significance for surgical approach, Terminologia Anatomica does not include a specific term to name this fibro osseous canal (FICAT, 1998) that permits replacing the eponym Dorello.

\section{MATERIAL AND METHOD}

For this study, 74 adult dry and complete skulls and 6 fresh heads, belonging to the Laboratory of
Anatomy, University of Caldas and the Autonomous University of Manizales were selected. We did not take into account whether they belonged ethnic groups or gender. As inclusion criteria, we considered all those skulls that had in good condition, the middle cranial fossa and the apex of the petrous temporal region. With an electric hasndsaw calvaria were sectioned to reveal the middle cranial fossa. Then, by gross inspection, the apex of the petrous region was localized to establish whether or not the canal for abducens nerve occurs bilaterally or unilaterally.

\section{RESULTS}

From 80 skulls, 68 were selected for this study, discarding 12 of them for not having undamaged area evaluated. Existence of bilateral abducens nerve canal for the 57 skulls, which corresponds to $83.82 \%$ found; in another 3 it was found unilaterally to the right, which corresponds to $5.89 \%$; four (4) skulls the left presented unilaterally to 5.89 $\%$. Finally, 3 skulls showed no canal for abducens nerve, which amounts to $4.41 \%$ (Figs. 1 and 2).

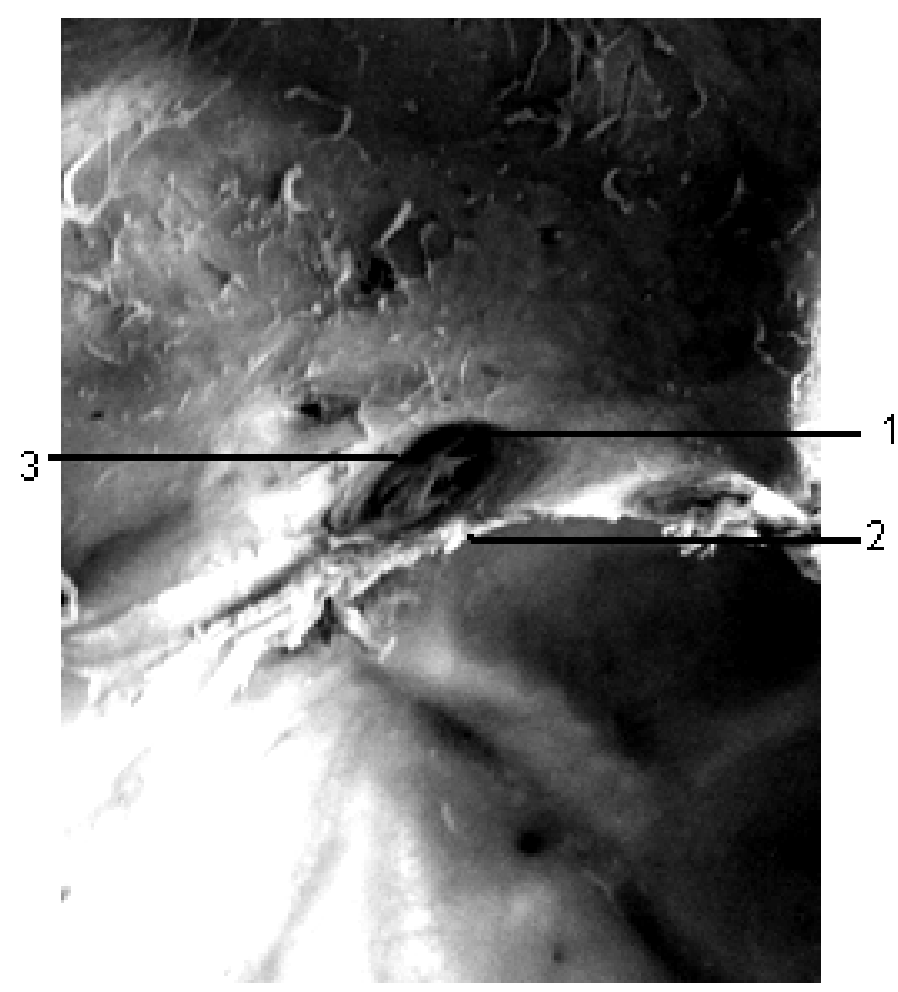

Fig. 1. The abducens nerve (1) located between bone concavity and petrosphenoidal ligament (2) is displayed. Dorello's canal dura mater is covered by (3).

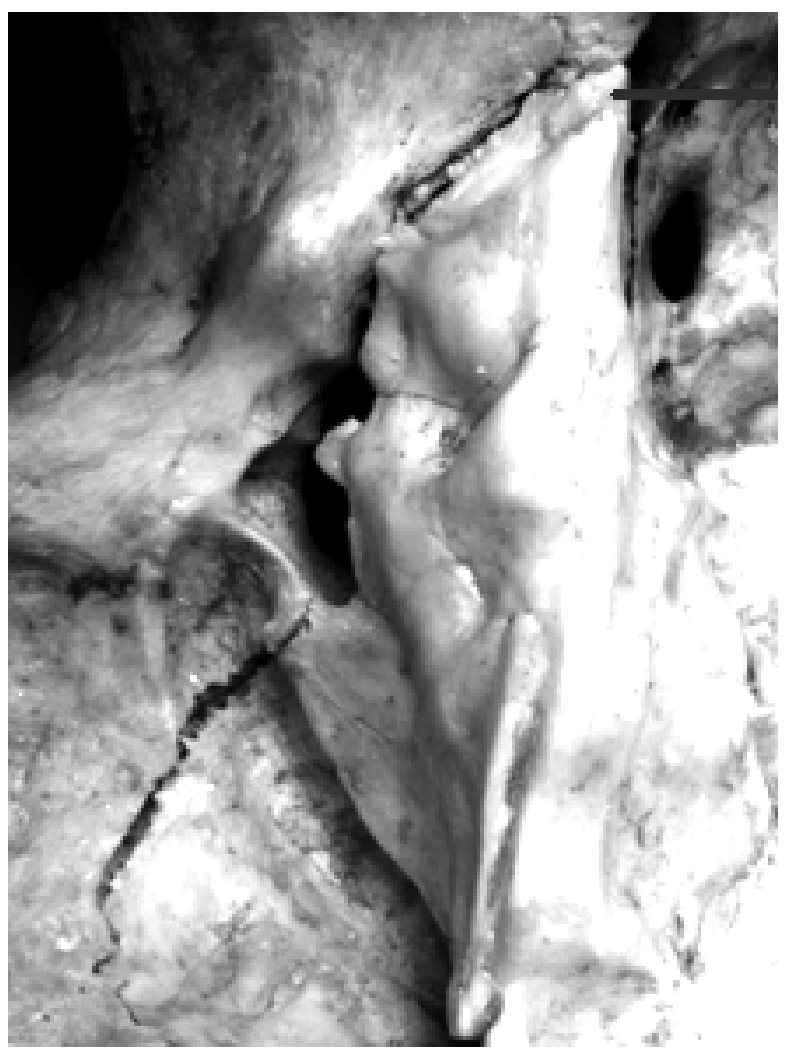

Fig. 2. The end of the red line indicates bone shaped concavity Dorello's canal. 


\section{DISCUSSION}

In the literature there are not many references to this specific area (Tsitsopoulos et al.,) and even less detailed descriptions Dorello's canal, gives the impression the canal does not exist, and the Terminologia Anatomica publication makes no mention of this fibro osseous landmark. Despite having been described in detail by Dorello in 1872, the few authors who have referenced it, denominate it the eponymous Dorello's canal.

However, the data emerging from our study indicates that there is high constancy of this fibro-osseous canal located at the apex of the petrous temporal region, and that in most studied skulls it presents bilaterally. In conclusion, it is necessary to confirm our results and corroborate these findings with other studies involving a larger sample and those that take into account ethnicity and sex.

Moreover, since there is in Terminologia Anatomica a specific term to name this landmark, we propose the name abducens nerve canal which is a more descriptive and precise term and informs the reader what it actually is, which does not occur when using the eponym Dorello's canal.

DUQUE, P. J. E.; BARCO, R. J. \& MENDOZA, Z. J. El canal de Dorello o canal para el nervio abducente:¿Constancia o inconstancia?. Int. J. Morphol., 35(1):233-235, 2017.

RESUMEN: El "canal de Dorello" es un epónimo que hace referencia a un pequeño relieve osteofibroso, a manera de arco, ubicado a nivel del ápex de la región petrosa del temporal y por el cual pasa recostado el nervio abducente antes de llegar al seno cavernoso. Dicho relieve no se encuentra referenciado en Terminologia Anatomica, ni siquiera como estructura inconstante. Se seleccionaron 74 cráneos secos y completos de adultos y seis cabezas fijadas con formalina al $10 \%$, sin clasificarlos por grupos étnicos ni por sexo. Como criterio de inclusión, se escogieron aquellos que tuvieran en buen estado la fosa craneal media y el ápex de la región petrosa del temporal. 57 cráneos $(83,82 \%)$ mostraron presencia del canal en forma bilateral; $4(5,89 \%)$ lo mostraron unilateralmente a la derecha; 4 (5,89 \%) lo tenían unilateralmente a la izquierda y $3(4,41 \%)$ no presentaban el canal. Los resultados de este estudio señalan que este relieve óseo se presenta en la mayoría de los cráneos, incluso en forma bilateral. Puesto que no aparece referenciado en Terminologia Anatomica, proponemos el término "canal para el nervio abducente", con el fin de evitar el uso del término epónimo "canal de Dorello".

PALABRAS CLAVE: Región petrosa del temporal; Ápex; Canal; Nervio abducente; Terminología.

\section{REFERENCES}

Ambekar, S.; Sonig, A. \& Nanda, A. Dorello's Canal and Gruber's Ligament: Historical Perspective. J. Neurol. Surg. B. Skull. Base., 73(6):430-3, 2012.

Chua, C.; Cooper, L. L.; Wei, X. C. \& Ruddell, S. Recurrent sixth nerve palsy associated with a hypoplastic Dorello's canal. $J$. AAPOS., 15(4):392-4, 2011.

Destrieux,C.; Velut, S.; Kakou, M.K.; Lefrancq, T.; Arbeille, B. \& Santini, J.J. New concept in Dorello's canal microanatomy: the petroclival venous confluence. J. Neurosurg., 87(1):67-72, 1997.

Ezer, H.; Banerjee, A. D.; Thakur, J. D. \& Nanda, A. Dorello's Canal for Laymen: A Lego-Like Presentation. J. Neurol. Surg. B. Skull. Base., 73(3):183-9, 2012.

Federative International Committee on Anatomical Terminology. Terminologia Anatomica. Stuttgart, Thieme, 1998.

Felisati, D. \& Sperati, G. Gradenigo's syndrome and Dorello's canal. Acta. Otorhinolaryngol. Ital., 29(3):169-72, 2009.

Forbis, P. \& Bartrolucci, S. L. Stedman's Medical eponyms. Baltimore, Williams \& Wilkins, 1998.

Kshettry, V. R.; Lee, J. H. \& Ammirati, M. The Dorello canal: historical development controversies in microsurgical anatomy, and clinical implications. Neurosurg. Focus, 34(3):E4, 2013.

Liu, X. D.; Xu, Q. W.; Che, X. M. \& Mao, R. L. Anatomy of the petrosphenoidal and petrolingual ligaments at the petrous apex. Clin. Anat., 22(3):302-6, 2009.

Marom, A. A New Look at an Old Canal. Skull Base, 21(1): 53-8, 2011.

Ono, K.; Arai, H.; Endo, T.; Tsunoda, A.; Sato, K.; Sakai, T. \& Makita, J. Detailed MR imaging anatomy of the abducent nerve: evagination of
CSF into Dorello canal. Am. J. Neuroradiol., 25(4):623-6, 2004.

Shioya, A.; Takuma, H.; Shiigai, M.; Ishii, A. \& Tamaoka, A. Sixth nerve palsy associated with obstruction in Dorello's canal, accompanied by nodular type muscular sarcoidosis. J. Neurol. Sci., 343(1-2):203-5, 2014.

Tsitsopoulos, P. D.; Tsonidis, C. A.; Petsas, G. P.; Hadjiioannou, P. N. \& Njau, S. N.; Anagnostopoulos, I.V. Microsurgical Study of the Dorello's Canal. Skull. Base. Surg., 6(3):181-5, 1996.

Umansky, F.; Elidan, J. \& Valarezo, A. Dorello's canal: a microanatomical study. J. Neurosurg., 75 (2):294-8, 1991.

\section{Corresponding author:}

Dr. Jorge Eduardo Duque Parra

Departamento de Ciencias Básicas Biológicas

Universidad Autónoma de Manizales

COLOMBIA

E-mail: jorge.duque_p@ucaldas.edu.co

Received: 27-06-2016

Accepted: 27-12-2016 